\title{
THE PROPERTY OFFENDER IN THE CONTEXT OF PSYCHOLOGICAL PERSONALITY DISORDERS
}

\author{
Ladislav MARIŠ ${ }^{1}$
}

Review article

Abstract:
(the author of the article deals with the problem of the behavior of the offender
of the proprietary crime, carried out research in Slovakia and in the Czech Republic, and
presents the profile of the perpetrator of the property crime on the basis of these researches.
The author focuses on the psychological profile of the perpetrator in conjunction with
dissocial personality disorder. The reason for this review is to know the probability of
the possible variants of the perpetrators decision at the crime scene. The article is based
on the analytical part of the doctoral thesis, which is based on the theme of simulation
of the behavior (proceeding) of the property offender(s), whose aim is, inter alia,
appropriately to describe the property offender's decision making - during breaking into
object.
Offender, break in, typology, psychology, behavior.

\section{Introduction}

According to statistical indicators of criminality in the Slovak Republic from 2009 there is a decrease of offences, however the damage of these crimes is increasing, and in 2012, has reached more than 700 million euros in one year. For comparison, in the same year, this sum amounted to expenditure on the program "protection of public order and the security" of the budget of the Ministry of Interior of the Slovak Republic. Crime against property accounts for about half of the number of detected offences and the average damage over the last five years, accounts more than 100 million euros per year.

Knowledge the creation, continuance and dissolution or other relevant characteristics of the property crime, we can contribute to the reduction of offences and damages of crime against property. We should focus on an analysis of the offender, which is the main subject in property crime. We believe that this knowledge can contribute for prevention activities such as, appropriately designed systems for the protection of property.

Systems for the protection of the property can be evaluated using mathematical models (Garcia, 2001). Literature (Loveček, 2011) describes the 4 basic models for assessment of the effectiveness of systems for the protection of objects:
- pessimistic model, which assumes that the intruder (the offender) knows all the necessary information about the protected object and so knows the path of least resistance (the path to the protected interest (assets) with the shortest time of resistance). This model eliminates the random (stochastic) impacts, which may act in an attempt to intrusion;

- realistic model, we consider impacts as in the first model, but are not constant, therefore, are random. Intruder knows all the necessary information (knows the path of least resistance). However, it is with the minimum values of the breakthroughs of the times (as in the pessimistic model). For random factors we can consider for example physical characteristics of intruder, experience or skills during intrusion;

- pragmatic model, which takes into account the decision-making of the offender with the uncertainty. A pre-requisite for this model is the ignorance (not know) of detailed information about the path of least resistance, and so the choice of moving is based on a rational (pragmatic) decision, based on knowledge and experience. It is therefore necessary to make sum number of simulations of intrusion to create a model, which describes the protected area. Then is possible to obtain estimates of the probabilities for the selection of individual zones, paths in object. (for example, the total time of break through barriers);

University of Žilina, Faculty of Special engineering, Department of Security management, Žilina, Slovak Republic, ladislav.maris@fsi.uniza.sk 
- and optimistic model, which is considered as the most benevolent from other models. This model reflects on delay of intruder during intrusion or with insufficient knowledge of the environment. Probability distribution describes the decisionmaking of intruder (choice of way, zone, etc.). (Loveček, 2011)

The problem is to know values of probability of intrusion ways, protected zones of penetration and escape from an object, or other parameters in the stochastic mathematical models. In this article we look at the psychological aspect of the offender of the property crime, which makes the probability of decision-making.

\section{Materials and methods}

The crime poses a specific phenomenon of the human activities that can be included in the troubles of the company. From the standpoint of the criminal law, crime is an action or omission that constitutes an offense that may be prosecuted by the state and is punishable by law. As we have indicated, the most common definition of crime means a summary of the crimes committed for a certain period of time. We include it among the most serious security risks.

According to the terms of the security management (Mikolaj, 2004) can be understood on the basis of the theory of common crime in the interaction of the following three elements:

1. the likely offender,

2. the adequate target of criminal activity,

3. the competent guardian (security measures).

The criminalistic theory describes three main types of crime based on animus crime, which can be devided in specific crime offences, consequent of the Criminal Code and Code of criminal.

The largest representation in the total crime in Slovakia for the period 2008 to 2012, in view of the number of offences has a property crime $(48.5 \%)$ and from the perspective of damage economic crime ( $80 \%$ of the total damage, in particular reducing the tax and embezzlement) followed by property crime (15\% of the total damage, theft, motor vehicle theft and burglary in particular). On the basis of the development of indicators of criminality in the Slovak Republic in the years 2008 to 2012 we can observe a descending trend in the number of detected offences. On the other hand the offenders caused by damage to the upward trend. While in 2008 and in 2009, the number of detected offences and damage indicators do not change significantly, there has been a reversal in 2010 when detected offences decreased by approximately $10 \%$ for the calendar year. However, the damage caused last year increased by more than $48 \%$. The damage caused by burglary (breaking in) in the period from 2008 to 2012 reaches an average of 32.3 million $€$ per year, representing approximately $30 \%$ of the damage of total property crime (109 million. $€$ ) and approximately $5 \%$ of the total crime ( 589 million $€$ ). Fig. 1 shows the evolution of property crime "burglary" and the damage caused by this activity (Fig. 1). The sum of crimes is slightly reduced (year 2011 and 2012). Fig. 2 shows the indicators of damage (in millions of euros) total crime, property crime, and crime, burglary (on average) in the period from 2008 to 2012. (Ministry of the Interior of the Slovak Republic, 2013)

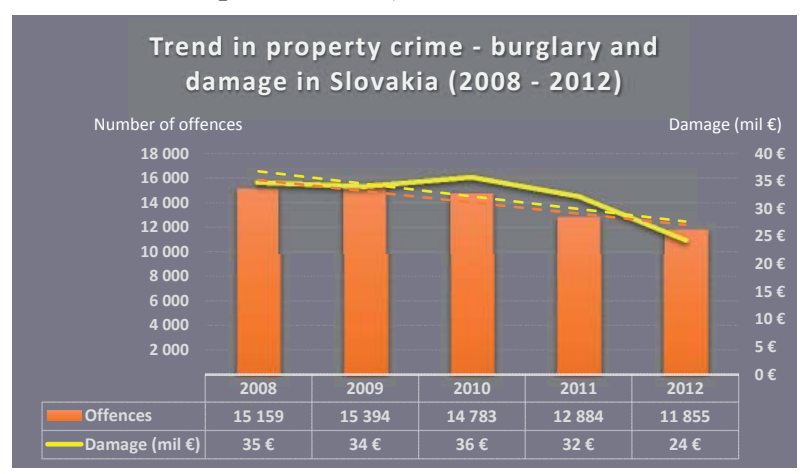

Fig. 1 Trend in property crime - burglary and damage in Slovakia between 2008 and 2012 (Ministry of Interior of Slovak republic, 2013)

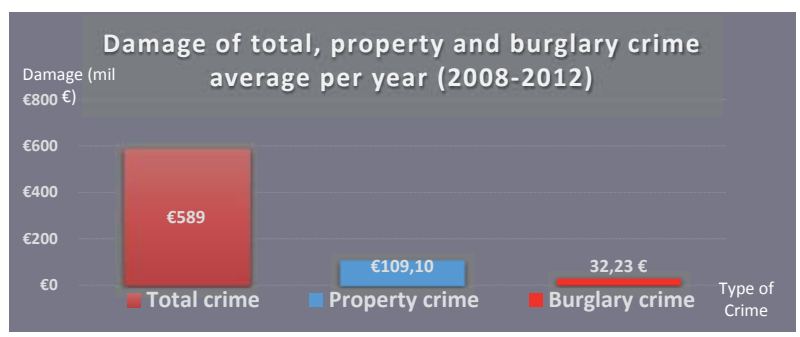

Fig. 2 Damage of total, property and burglary crime (average per year) in years in 2008 to 2012

(Ministry of Interior of Slovak Republic, 2013)

From the perspective of the protection of property against property crime theft we will focus on the terminology terms like offender, theft, burglary or intruder and other terms of the for a better orientation in this area.

Due to Criminal Code of Slovak republic is theft defines:

„Offences against property“, and „,any person who appropriates a thing belonging to other by seizing it and thus causes damage" by acting desribed in the Criminal Code (Criminal Code of Slovakia, 2005), such as housebraking (burglary). 
The criminal offence housebreaking is defines: "If the offender entered enclosed premises by unauthorised forcing of a lock, or by forcible overcoming of a different security device, or by deception."

This Acting in a more serious manner shall mean that a criminal offence was committed by deception. (Code, 2005)

Crimininalistic theory defines basic criminalistics categories:

- method (way) of commiting a criminal offence,

- criminalistic trace,

- and criminalistic identification. (Porada, 2007)

Ways of committing the offence constitutes the most important and at the same time the greater part of the characteristics of criminal offence (the description of the relevant characteristics of the crime, which affect the process of making traces and process of the knowledge criminal offence). This method of analysis in respect of the person of the offender has importance of criminalistic, because it allows to type criminal offenders of housebraking. According to Porada:

"Quality analysis allows likely to answer the questions, which relate to the time or place of committing a criminal offence, the object of offenders interest, assess the skills and knowledge of the offender, his (her) psychical activity level, to consider age and gender, and many other factors." (Porada, 2007)

The Criminal Code of Slovakia defines the offender as:

„An offender of a criminal offence is the person who committed a criminal offence acting on his own. Only a natural person may be considered as the offender of a criminal offence." (Code, 2005)

The Criminal Code knows term the accomplice: „If a criminal offence was committed by two or more persons acting in conjunction (accomplices).“ (Code, 2005)

The criminology as scientific study of the nature, extent, causes, control, and prevention of criminal behavior in both the individual and in society, understands the offender:

„Not only the persons who have committed offences identified by criminal code as criminal offences, but also some persons, which the criminal proceedings not prosecute." (Novotny, 2008)

The offenders' characteristics are used for the needs of Criminalistic (Forensic Science), Psychiatry, Psychopathology or Criminal law. The basic concept that is used in the context of the above fields is the term of the personality of the offender.

The Criminology defines the personality of offender as:

„Organic whole intellectual life of man involved a biological basis of the individual, as well as to the social conditions of his life, including social relations." (Gašpierik, 2012)

Deeper, personality of the offender, we can be understood as:

„Organized, dynamic and interindividual different the whole of psychophysical dispositions, determinated the continuances and badges of psychic processes (reactions), reflected in the behaviour and negotiations." (Nakonečný, 1993)

Knowledge of the behaviour and negotiations of the offender of criminal offences (knowledge of offender), can anticipate or prevent this offence. In the case, where the person in object is an unauthorized person, it is not correct to use the term offender (if not proven guilty - committing the offence). In this case, we should use the term intruder, where we understood:

„Any person who unlawfully enteres (or is located) in the guarded area or protected area or simply in the object (building).“ (Mikolaj, 2004)

Typology of offender profiles represents attempts to work out the characteristics of an offender (or offenders) from the characteristics of their offences. It can be used as an adjunct to conventional police work to help police link crimes, focus their investigation and narrow the suspect field. Typological profiling focuses primarily on behavioural evidence obtained at the scene(s) of specific crime(s). This method makes it possible to sort according to certain criteria, delinquents' characters or characters into groups, each of which can be characterized by a certain pattern, prototype and type. On the basis of empirical studies, however, the "clean" types within the typology of offenders do not exist, but it is always "only" about approaching one, for the purposes of dividing, defined type. (Porada, 2007)

Typology of offender defines 3 main characteristics:

- biological disposal of personality,

- psychological disposal of personality,

- and social environment.

However, from the perspective of the Criminalistics and Psychology of human behaviour we know that human behaviour is in some way determined, therefore, depend on many factors. 
Ways of committing the offence constitutes has its factors, which:

1. are related to offender (subjective determinants):

- physical characteristics of the offender,

- psychical and motoric characteristics of the offender,

- age of the offender,

- gender of the offender,

- the previous criminal experience of the offender,

- education of the offender,

2. are not related to offender: (objective determinants):

- social conditions,

- an object of offence,

- relationship between the offender and the attack and the scene of the crime,

- scene of the crime,

- time of committing the offence,

- availability of tools, weapons and other devices,

- existence of accomplices. (Porada, 2007)

For example, we can divide the offender in pointo of view criminal experience as:

- "the first time offender" - has not crime experiences, comits the offence in the first time,

- "the recidivous offender" - has crime experiences, frequently comits the offence.

In the field of the property offender's typology, Criminology and Criminalistics is based on offender's studies that are focused on the entire spectrum of relevant characteristics to committing a crime. The first professional study in this field, which is dealing with the crime and the offender on the territory of the Czechoslovakia, is a still from 1931. The author published his work "Zločinnost v zemích českých v létech 1914 - 1922 s hlediska kriminální etiologie a reformy trestního práva." (APZ SR, 2012)

Relatively more research activity occurred in the second half of the the $20^{\text {th }}$ century. Studies of offenders between the years of 1970 and 1980 carried out "Criminological Research Institute at the General Prosecutor's Office of the Czechoslovak socialist republic" and the "Research Institute at the Ministry of Justice of Czechoslovakia". These studies include a prediction of further processing behaviour of the offenders groups (adolescents, women, etc.) and to part offenders into groups in prison establishments in order to improve the work with offenders in criminal practice. In the 80's years, on the basis of the above studies developed and the abstract personality of the offender with mental health characteristics. The majority of studies showed the differences in the specific values and characters of the observational group and a control group of offenders. (Novotný, 2008)

By Marešová (Novotny, 2008), was devoted to similar research, after the formation of a separate Slovak and the Czech Republic did not explore about 10 years the characteristics of offenders. In the year 2000 in the Czech Republic have started to explore the properties of the arrested offenders aimed at users of addictive substances, juvenile offenders, foreigners in the Czech Republic for the first time whether arrested offenders. Marešová adds that:

"The results did not validate the opinion, that the offenders are a separate group of personalities with specific differences, such as psychical characteristics and structure of personality, opposite to the others (not criminal cititzens)." (Novotny, 2008)

One of the first studies since separation of Czechoslovakia, which were made with a point of view to examine the offenders typology in selected prisons of Czech Republic brought interesting results. The results of the research are described by the Maroš Matiaško in his thesis "Personality of the offender of property crime in the context of Cloninger's biosocial theory of personality" in the year 2008 under the Masaryk University in Brno. The author in the work considered the presence of personality disorders in a research file, which consisted of property crime offenders, arrested in the Czech Republic. The author has attempted to classify these offenders based on the Cloninger theory, which is based on assumption that:

„Personality is a complex system which consists of different psychobiological dimensions of temperament and character. Temperament and character are measurable and allow to assess the differences between people. (Matiaško, 2009)

According to Matiaško, the number of recidivous property offenders with personality disorder is many times higher than in the general population. (Matiaško, 2009)

According to the World Health Organization (WHO), it is possible to distinguish 10 types of personality disorders:

1. paranoid personality disorder, where the typical symptoms is to high sensitivity to own person, especially to real or suspected rejection, repulsion. We observe vigilant, hostile and aggressive behavior to their environment;

2. schizoid personality disorder, where we can observe a personality typically very closed, which 
have few or none close relationships. Affected individuals may simultaneously demonstrate a rich, elaborate and exclusively internal fantasy world;

3. antisocial personality disorder, manifests the major problems of the relationship between individuals and society in which he/she lives with this disorder. The most common behaviour associated with antisocial effects to common standards and rules of behaviour, including a disrespect, infringement of the law. There may be an impoverished moral sense or conscience and a history of crime, legal problems, impulsive and aggressive behavior. Accordind to Heretik (Heretik, 2009):

"... according to the classification of diagnostic criteria, it is estimated that antisocial personality disorder occurs in about $3 \%$ of the general adult population, but more than $60 \%$ of the prison population;"

4. borderline personality disorder (called emotionally unstable personality disorder) is a personality disorder whose essential features are a pattern of marked impulsivity and instability of affects, interpersonal relationships, and self image. The pattern is present by early adulthood and occurs across a variety of situations and contexts;

5. histrionic personality disorder is characterized by a pattern of excessive emotions and attentionseeking, including inappropriately seductive behavior and an excessive need for approval, usually beginning in early adulthood. People affected by this disorder are lively, dramatic, vivacious, enthusiastic, and flirtatious. It has a prevalence of $2-3 \%$ in the general population, and $10-15 \%$ in inpatient and outpatient mental health institutions;

6. obsessive-compulsive personality disorder also called anankastic personality disorder, is a personality disorder characterized by a pervasive pattern of preoccupation with orderliness, perfectionism, mental and interpersonal control at the expense of flexibility, openness, and efficiency. The main symptoms are preoccupation with remembering and paying attention to minute details and facts, following rules and regulations, compulsion to make lists and schedules, as well as rigidity/inflexibility of beliefs or showing perfectionism that interferes with task-completion;

7. avoidant personality disorder, also known as anxious personality disorder. People with avoidant personality disorder often consider themselves to be socially inept or personally unappealing and avoid social interaction for fear of being ridiculed, humiliated, rejected, or disliked. Avoidant personality disorder is usually first noticed in early adulthood;

8. dependent personality disorder (formerly known as asthenic personality disorder) is a personality disorder that is characterized by a pervasive psychological dependence on other people. This personality disorder is a long-term condition in which people depend on others to meet their emotional and physical needs, with only a minority achieving normal levels of independence;

9. and other personality disorders. (Heretik, 2009)

A short description of the typical personality disorders showed up at the interaction of property crime offenders research (Matiaško, 2009) and in particular, antisocial personality disorder.

\section{Results}

A psychological profile of the offender is not clearly validable, which supports the claim Merešová. However, from the above studies from the environment of prison and environment of clinical psychology, we can say, that:

"The probability of repetition crime is related to personality disorder of offender (especcialy antisocial personality disorder, present in recidivous offenders)."

If the person is not directly connected with the personality disorder, probably will have a tendency to this disorder. (Matiaško, 2009)

In the dissertation of Polišenská (Polišenská, 2006) claims, that up to $33.3 \%$ of the housebreaking offenders suffers from personality disorder. Together with the other offenders with tendency to personality disorder, can mean more than half of the arrested for property crime. Most often connected criminal behaviour with antisocial personality disorder. This disorder can be based on the hereditary dispositions, but a risk factor for this disorder is also a negative situation in the family during adolescence. Antisocial personality disorder is linked to a higher risk of adolescence in housing estates, with high unemployment, crime and drug abuse in the region. This person often has problems with the police or directly with the criminal environment during school age. We can for this person to observe the low degree of regret for his offence. Often the person with the antisocial disorder do not want (or are not) to motivate to change their ways of life. There is an increased risk of substance abuse behavior, failure, 
gambling, depression, and also sexually transmitted diseases. A man with antisocial personality disorder may pretend an interest for cooperation, but only when he wants. There is a high risk of lying or manipulation of the social environment.

According to (Matiaško, 2009), there is more than a fifth of the property offenders, who are impulsive, nonsystematic and usually easy to get bored. On the other hand, he adds that these characteristics could also arise during the duration of the previous arrest. Interesting is also the argument that the recidivous offender has a feeling that his destiny is to be convict. He also adapts to the situation that his life will unconsciously spend in prison and in freedom. The recidivous offender:

"He do not take sentence as a real punishment, but as a necessity, which was preceded by their own situational mistakes (acknowledgement, own failure, miscalculation of the situation).”

\section{Conclusion}

This article points to the offender in the context of personality disorder. A psychological profile of the offender is one of the many aspects of the decision-making process of his intrusion to protected area. We can say the hypothesis that the psychological disposition of the offender affects the decisions of the selection the route, the penetration and used devices for intrusion.

In the following phases we will examine decision-making process of the real offenders by interview and questionnaire method in cooperation with the prison psychologist. We compare our results with the results from criminalistics investigators and with the results of computer simulation.

\section{Acknowledgments}

This contribution was undertaken, as parts of the research project VEGA 1/0743/11Support of personal and property security on a municipal level.

\section{References}

GAŠPIERIK, Libor et al. (2012). Osobnost’ páchatel’a. Žilina: Žilinská univerzita. 2012. ISBN 978-80-554-0554-4. (in Slovak)

GARCIA, Mary Lynn. (2001). The design and evaluation of physical protection systems. Bur-lington (USA): Elsevier. 2001. ISBN - 13: 978-0-7506-7367-9.

HERETIK, Anton (2009). Poruchy osobnosti [online]. Zdravie.sk. 2009. [cit. 2013-02-04]. Avalaible at: http:// www.zdravie.sk/choroba/39612/poruchy-osobnosti\#5-priciny-vzniku-poruch-osobnosti. (in Slovak)

Katalóg knižnice Akadémia Policajného zboru Slovenskej republiky (2012). CEIT, [cit. 2013-02-04]. Avalaible at: http://proxy.ceit.sk/webisnt/kniznicaapz.htm. (in Slovak)

LOVEČEK, Tomáš, REITŠPÍS, Josef (2011). Projektovanie a hodnotenie systémov ochrany objektov. Žilina: Žilinská univerzita. 2011. ISBN 978-80-554-0457-8. (in Slovak)

MATIAŠKO, Maroš (2009). Osobnost' recidívneho páchatel'a majetkovej trestnej činnosti v kontexte Cloningerovej biopsychosociálnej teórie osobnosti. Brno: Masarykova univerzita, 2008. [cit. 2013-02-04]. Avalaible at: http:// is.muni.cz/th/182283/fss_b/Bakalarska_praca.M aros_Matiasko.doc. (in Slovak)

MIKOLAJ, Ján et al. (2004) Terminológia bezpečnostného manažmentu. Košice: Multiprint, 2004, 191 s. ISBN 80-969148-1-2. (in Slovak)

Ministerstvo vnútra Slovenskej republiky (2013) Štatistické údaje kriminality [online]. [cit. 2013-02-04]. Avalaible at: http://www.minv.sk/?statistika-kriminality-v-slovenskej-republike-xml. (in Slovak)

NAKONEČNÝ, Milan (1993). Základy psychológie osobnosti. Praha: Management Press, 1993 (in Czech)

NOVOTNÝ, Oto, ZAPLETAL, Josef, et al. (2008). Kriminologie. 3. vyd. Praha : ASPI - Wolters Kluwer. 2008. s. 119. ISBN 978-80-7353-376-8. (in Czech)

POLIŠENSKÁ, Veronika, Anna (2006). Burglars. The influence of personality and place-attachment upon spatial behaviour. [online]. Dissertation. Masarykova Univerzita, Fakulta sociálnich studií, katedra psychológie. 2006 [cit. 2013-02-04]. Avalaible at: http://is.muni.cz/th/52930/fss_d/Polisenska_disertace.pdf

PORADA, Viktor, et al. (2007). Kriminalistika. Bratislava: IURA EDITION. 2007. ISBN 978-80-8078-170-5. (in Slovak)

The National Council of the Slovak Republic Act No. 300/2005 collection of laws of the Slovak Republic as amended by later regulations - Criminal Code. 